\title{
FANTASTIC CREATURES AND WHERE TO FIND THEM IN THE ILIAD
}

\author{
Camila Aline Zanon* \\ Recebido em: 04/10/2019 \\ Aprovado em: 25/10/2019
}

\begin{abstract}
As a poem centered on war, the Iliad is not considered to be endowed with the element of the fantastic as is the Odyssey. There are, however, mentions or allusions to some creatures fought by heroes of previous generation, like Heracles and Bellerophon, along with some brief mentions to other fantastic creatures, like the Gorgon, the centaurs, Briareus and Typhon. This paper aims to locate those brief presences in the broader narrative frame of the Iliad.
\end{abstract}

KEYWORDS: Early Greek epic poetry; Homer; Iliad; monsters.

\section{CRIATURAS FANTÁSTICAS E ONDE ENCONTRÁ-LAS NA ILÍADA}

RESUMO: Enquanto um poema centrado na guerra, não se considera que a Ilíada seja dotada do elemento fantástico como a Odisseia. Há, contudo, menções ou alusões a algumas criaturas combatidas por heróis da geração anterior, como Héracles e Belerofonte, junto com algumas breves menções a outras criaturas fantásticas, como a Górgona, os centauros, Briareu e Tífon. Este artigo pretende localizar essas breves presenças no enquadramento narrativo mais amplo da Ilíada.

PALAVRAS-CHAVE: Poesia épica grega arcaica; Homero; Ilíada; monstros.
* Post-doctoral researcher at the Departamento de Letras Clássicas e Vernáculas, Universidade de São Paulo, grant 2016 / 26069-5 São Paulo Research Foundation (FAPESP). camila.zanon@gmail.com 


\section{INTRODUCTION $^{1}$}

T $\mathrm{n}$ his 'The epic cycle and the uniqueness of Homer,' Jasper Griffin (1977) sets the different attitudes relating to the fantastic as a criterion for establishing the superiority Lof Homer's poems over the Epic Cycle. The Iliad, he says, is 'more cautious with the fantastic,' while ' $[\mathrm{t}$ he fantastic, the miraculous, and the romantic, all exceeded in the Cycle the austere limits to which the Iliad confines them' (Griffin, 1977, p. 40). That alleged caution towards the fantastic comes as a yardstick for judging the 'exceptional genius' behind the Iliad to the detriment of the cyclic poets, whose poems are 'still content with monsters, miracles, metamorphoses, and an un-tragic attitude towards mortality, all seasoned with exoticism and romance, and composed in a flatter, looser, less dramatic style' (Griffin, 1977, p. 53). ${ }^{2}$

Although I cannot agree with the use of 'fantastic' as a derogatory benchmark enough in itself to judge the quality of a literary work, indeed the Iliad, as a poem centered on the very real matter of war, does not present us with narratives in which the main characters come across creatures like the ones we find in the Odyssey - Polyphemus, the Sirens, Scylla, and Charybdis. ${ }^{3}$ The present paper focuses on those instances in the Iliad in which the poet does provide us with a particular kind of the so-called 'fantastic': the creatures usually regarded as monsters.

First, we must be more precise about what we mean by the very term 'fantastic'. The notion of what is real is historically determined and defined, changing through time, and the same is true for the fantastic as synonym of what is not real in opposition to a supposedly objective reality. As we live in a world that has been through the historical process of 'disenchantment', as Max Weber called it - meaning the process of stripping the gods from the world and replacing them first with a single god, then with science -, our notion of real and unreal differs greatly from the ones pertaining to societies that have not been through that process. ${ }^{4}$ Hence, when we deal with early Greek poetry, it is necessary to remember that its world is fully inhabited by gods, not themselves perceived as out of this world, but as an integral part of it. That enchanted poetry, by its turn, was itself a product

\footnotetext{
${ }^{1}$ This article is a revised and more detailed version of the paper I delivered at the colloquium 'A Ilíada de Homero e sua recepção na Antiguidade e modernidade'. I would like to thank Adrian Kelly for the helpful remarks about Heracles stories in the Iliad and for making available to me some years ago the work of James O’Maley (2014). I would also like to express my gratitude to Adrian, to my partner Uiran Gebara da Silva, and to my supervisor Christian Werner for generously giving their time to read a first draft of this paper and for their valuable suggestions.

2 Griffin's article does not provide us with a definition of what he is calling 'fantastic', besides the 'bizarre features' that 'are not tolerated in Homer, where real humanity is insisted upon for all characters' (Griffin, 1977, p. 41). His notion of the fantastic does not apparently include the gods and their actions.

${ }^{3}$ There is, however, a fight between Achilles and the river-god Scamander (Il. 21, 1-384), an episode to which I will return later.

${ }^{4}$ For a full treatment of the concept of 'disenchantment of the world' in Max Weber, see Pierucci (2013).
} 
of an enchanted world in which the poets lived and that did not separate the gods from the immediate daily life of its inhabitants. ${ }^{5}$

When the gods are immanent to the cosmos, not being apart from it, that directly affects the way people interact with the world. In a non-disenchanted world, the concept of real and unreal does not reflect what exists and what does not, but only what the gods make possible to exist. The existence of a being with only one eye is as plausible as a rainbow for they can be both attributed to the divine presence in the world. The world the Iliad renders, or even the world that shaped the tradition to which the Iliad belongs, does not establish a difference between what is real and unreal in our terms, for everything can be explained as having a divine origin and can be attributable to a god, no matter how unrealistic it may seem for us, inhabitants of a modern and disenchanted world. ${ }^{6}$

For the sake of argument, I will use a brief and simple working definition of 'fantastic' that seems to function better for the poems of Homer and Hesiod than the blanket and vague ontological opposition 'real versus unreal'. As a product of an enchanted world, the fantastic does not equate to 'fiction' as opposed to 'objective reality', but it is rather epistemological and aesthetical, involving the reaction of amazement. The verb $\theta \alpha v \mu \alpha$ çsv ('wonder at') and the noun $\theta \alpha \tilde{v} \mu \alpha$ ('wonder', 'marvel') are a frequent expression of that amazement towards the extraordinary things and events the gods make available to mortal eyes and ears.

The creatures we regard as monsters are among the extraordinary elements that inform those poems. Although they do not take part in the main narrative of the Iliad, they appear mostly in embedded narratives within a character's speech about the past. ${ }^{7}$ That past

${ }^{5}$ For the question whether the ancient Greeks believed in their myths, I tend to follow Veyne (1983) and Versnel (2011).

${ }^{6}$ Regarding the relation between the Iliad and the fantastic, I find Nagy's approach (2013) more sensitive to the differences between our perspective and the primary audience's: 'Admired through the ages as the ultimate epic, Homer's Iliad, along with its companion-piece, the Odyssey, was venerated by the ancient Greeks themselves as the cornerstone of their civilization. By force of its prestige, the Iliad sets the standard for the definition of the word epic: an expansive poem of enormous scope, composed in an archaic and superbly elevated style of language, concerning the wondrous deeds of heroes. That these deeds were meant to arouse a sense of wonder or marvel is difficult for the modern mind to comprehend, especially in a time when even such words as wonderful or marvelous have lost much of their evocative power. Nor is it any easier to grasp the ancient Greek concept of hero (the English word is descended from the Greek), going beyond the word's ordinary levels of meaning in casual contemporary usage'.

${ }^{7}$ For the embedded narratives (also called para-narratives) in the Iliad, I generally follow Alden (2001). For the paradigmatic character of those stories, see Austin (1966). See also O’Maley (2014), though I do not agree with his argument that they have a status of mere footnotes in Homer. Kelly's analogy to hypertext is more suitable in that it does not belittle their significance (Kelly, 2010). The embedded narratives in the Iliad are a poetical device by which the poet can not only display his knowledge of the various narratives that conform the tradition within which he operates but, more importantly, they are a crucial tool through which he embeds the Iliad in a broader tradition of early epic poetry. The oime ('path') that the poet established for the Iliad does not allow those episodes to be part of the 
involves the generation of heroes like Heracles and Bellerophon, so-called 'monster-slayer' heroes, who belong to the generation before the one fighting at the gates of Troy. ${ }^{8}$

Before turning to the creatures in the Iliad, I would like to make one remark about the notion of 'monster' in early epic poetry. There is no such word in that poetry, for even the ones usually translated as 'monster' - $\tau \dot{\varepsilon} \rho \alpha \varsigma$ (teras) and $\pi \dot{\varepsilon} \lambda \omega \rho$ (pelōr) - do not mean 'monster', but 'prodigy' or 'portent', referring to something extraordinary shown or sent by the gods, usually to convey a message to humans. 'There is no indication that the creatures we call 'monsters' were perceived as belonging to a category as such, and many of those creatures were immortals like the gods; even the mortal ones usually descend from a divine lineage. Since in early Greek epic the divine is not just an aspect of the cosmos, but it is as much a part of it as the earth, the sky, and the mountains (which are themselves perceived as gods), then creatures like the Cyclopes, the Hundred-Handers, the Chimera, Typhon, and so forth are also perceived as divine. As already stated here, that world is full of gods and what we call monsters are as well manifestations of the divine in the world.

I will address each creature mentioned in the Iliad separately. First, I will deal briefly with the Gorgon, which does not appear in an embedded narrative, and then I will turn to the ones that are found in that context, namely, the centaurs, Briareus, 'the dog of Hades' and the sea-creature in Troy - these last two put together because they are mentioned in relation to Heracles -, and finally the Chimera. Although Typhon is not in character's speech either, I categorize him with Briareus as they are both part of the story that accounts for Zeus' ascension to power, narrated in Hesiod's Theogony.

\section{THE Gorgon}

In the Iliad, the Gorgon is mainly a shield device (with one exception: 8, 349), on the goddess Athena's aegis (Il. 5, 741-2) and on Agamemnon's shield (Il. 11, 36-7).

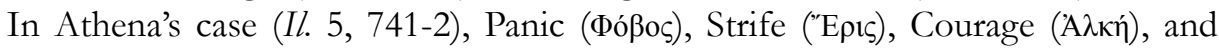
Pursuit (Iڤк'́), personifications that can be related to battle, accompany the Gorgon head. ${ }^{10}$ The accumulation of qualifiers in lines $I l .5,741-2$ emphasizes the head's terrifying factor: 'and the Gorgonian head of terrible prodigy, / terrible and horrifying, a portent of Zeus

main narrative, but the poet's skill allows him to evoke them in moments he finds adequate during his performance, extending and embellishing his narrative as well as anchoring it in a wider tradition. ${ }^{8}$ The problem concerning the notion of hero in Homer's poem has already been indicated in Nagy's citation in footnote 7 above. When the word hero is used in this paper, it does not mean the hero in the modern sense, as the super-hero who saves people from danger and whose moral obligation is to protect humanity from evil. For a discussion of the concept of hero in archaic epic, see Nagy (2013). ${ }^{9}$ Cf. Zanon (2018, p. 65-98). Although the nouns ' $\pi \dot{\lambda} \lambda \omega \rho$ '/ $\pi \dot{\lambda} \lambda \omega \rho \circ v^{\prime}$ are often translated as 'monster', our sense of the word 'monster' has long lost the meaning of a sign of the gods.

10 'A blazon can inspire terror as well as identify the bearer [...].' (Hainsworth, 1993, p. 221). In Pseudo-Apollodorus' Bibliotheca (2, 38-46) Athena places the head of the Gorgon Medusa on her shield after Perseus had killed her with the help of the goddess. 


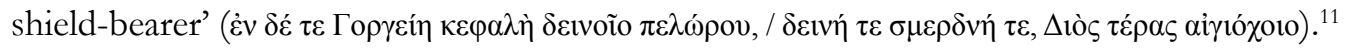

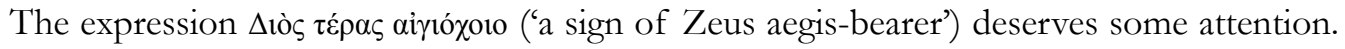
The nouns $\pi \dot{\varepsilon} \lambda \omega \rho / \pi \dot{\varepsilon} \lambda \omega \rho o v$ and $\tau \dot{\varepsilon} \rho \alpha \varsigma$ are linked etymologically and have similar semantic fields, with $\pi \dot{\varepsilon} \lambda \omega \rho / \pi \dot{\varepsilon} \lambda \omega \rho$ ov being the Aeolic variant of $\tau \dot{\varepsilon} \rho \alpha{ }^{12}{ }^{12}$ They both carry the meaning of 'portent' or 'prodigy', expressing something out of the ordinary that can be interpreted

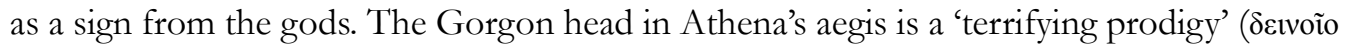

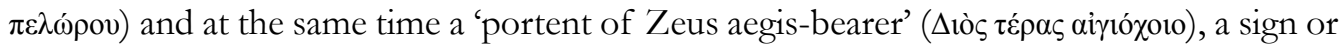
an emblem that evokes the most powerful god in his protective and defensive aspect. Here, it is not only the fear the Gorgon head on a shield can provoke in an enemy that accounts for its apotropaic function, but also its connection to the defensive power of Zeus. ${ }^{13}$

In the case of Agamemnon's shield, we do not find the same lines referring to the

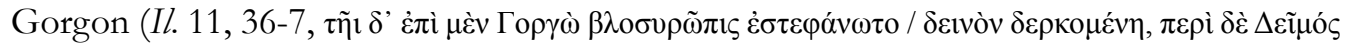

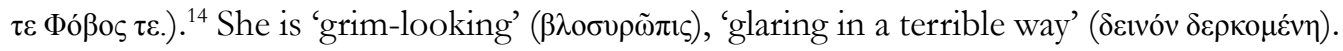

${ }^{11}$ All translations are mine and they aim to be as literal as possible. Notice the repetition of the

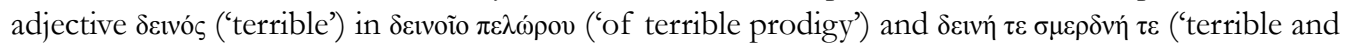

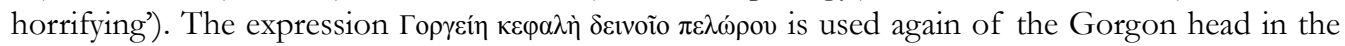

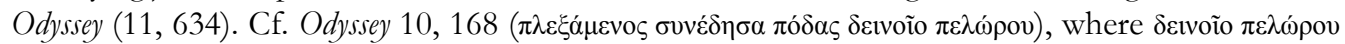

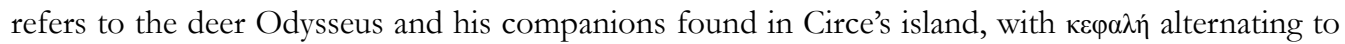

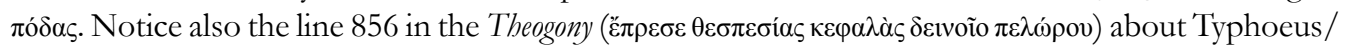

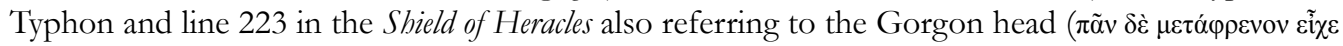

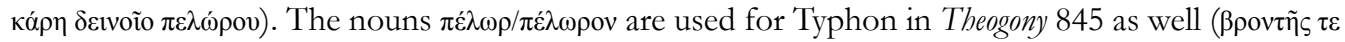

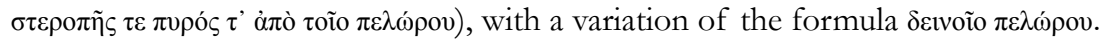

${ }^{12}$ Cf. the entries $\pi \varepsilon \dot{\lambda} \omega \rho$ and $\tau \dot{\varepsilon} \rho \alpha \varsigma$ in Chantraine's and Beekes' etymological dictionaries.

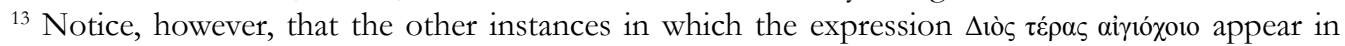
Homer are not related directly to a shield but to signs sent by Zeus, as in Iliad 12, 290 where there is no shield involved, but a snake is referred as a prodigy sent by 'Zeus aegis-bearer'. In Odyssey 16, 320 we can see a similar use when Telemachus addresses Odysseus. From those two passages, it becomes

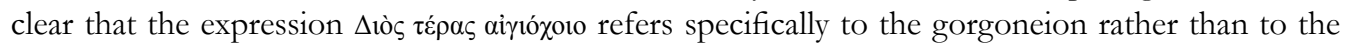

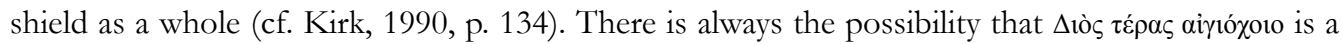
formulaic way to refer to portents and prodigies, as they are considered to be sent by Zeus. The use of the formula in those passages seems to indicate that a portent as a sign sent from a god, usually Zeus, and a creature like the Gorgon are strongly connected semantically in the language of early epic in an inextricable way.

${ }^{14}$ Here, the lines are somewhat different from the ones used to describe Athena's aegis and there is no mention to Zeus. Athena and Agamemnon are associated with Zeus in different manners: Athena as Zeus' warrior daughter and Agamemnon as the commander-in-chief of the whole army, whose authority derives from Zeus. It is, then, appropriate that they have a sign of Zeus on their shield, although that relation between the Gorgon head and Zeus is not made explicit in the description of Agamemnon's. Maybe the narrator did not want to draw Athena and Agamemnon so close together avoiding the same formula for both shields. 
Instead of being surrounded by four personifications like in Athena's aegis, she is here surrounded only by $\Delta \varepsilon \mu$ ós (Terror) and Фóßos (Panic). ${ }^{15}$

The only reference to the Gorgon not as a shield device falls at Il. 8, 349, in relation to Hector. When he is successfully driving an attack against the Achaeans and pushing them to the ditch that protects the Greek camp, the narrator says Hector has the eyes of a Gorgon or of Ares. ${ }^{16}$ Given the power and violence of his attack, it is understandable that he is then associated with a frightening creature, his glare as horrifying as the Gorgon's. At that moment Hector's look seems to work as a practical manifestation of the shield device's desired effect.

\section{The CENTAurs}

The centaurs are mentioned in a speech made by Nestor (Il. 1, 254-84) and by the main narrator in the catalogue of ships (Il. 2, 738-47). The centaur Chiron, particularly, is referred to four times: once in a speech by Eurypylus to Patroclus $(I l .11,823-35)$ and three times by the main narrator (Il. 4, 219; 16, $143=19,390)$.

In order to convince Achilles and Agamemnon to take his advice and end their quarrel, Nestor first sets his authority by his age and then by declaring that he once was among better men who took his advice. Those men were the 'mightiest', who also fought against the 'mightiest', whom no mortal in the present generation would fight $(I l .1,272)$

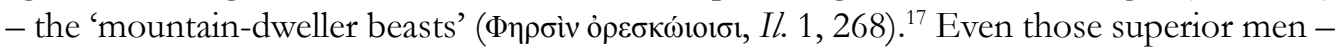

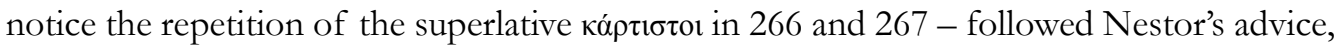
making it thus better for Agamemnon and Achilles to do the same. ${ }^{18}$

Nestor does not present in his speech a description of the 'mountain-dweller beasts', nor does the main narrator in book 2 when he mentions the 'hairy beasts' ( $\Phi \tilde{\eta} \rho \alpha \varsigma_{. . .}$ $\lambda \alpha \chi v i \varepsilon v \tau \alpha$, Il. 2, 743) in the catalogue of ships (Il. 2, 738-47). There, when the poet presents

\footnotetext{
${ }^{15}$ The Gorgon or the Gorgon head is often depicted on shields in archaic Greek art, mainly pottery, associated more frequently with Achilles in the $7^{\text {th }}$ and $6^{\text {th }}$ centuries and with Ajax in the $6^{\text {th }}$. See Hainsworth's comment (1993, p. 221-2) on Il. 11, 36-7 for a bibliography on archaeological findings. See also the entry 'Gorgo, Gorgones' at the Lexicon Iconographicum Mythologiae Classicae (Ackermann; Gisler; Kahil, 1981; 'Literarische Quellen' by Stefan-Christian Dahlinger, p. 285-7, and 'Kommentar' by Ingrid Krauskopf, p. 316-30, both in v. 1; and v. 2 for the images, p. 163-86). As the Gorgon does not appear as an iconographic motive before $700 \mathrm{BC}$ and it is depicted as a shield blazon only from 670 BC onwards, West (2012, p. 236), considers it to be one of the elements that would corroborate the $7^{\text {th }}$ century as the most likely date for the Iliad.

${ }^{16}$ See $I l .15,605-14$, where Hector is again associated with Ares and his gaze is also mentioned but not associated with the Gorgon.

${ }^{17}$ On ó goats; probably therefore it means something close to "mountain-dwelling", with its second element

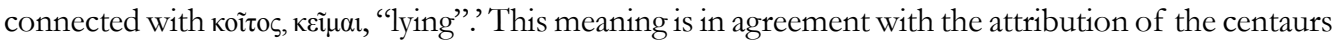
as dwelling on the slopes of Mount Pelion.

${ }^{18}$ For the other three long speeches by Nestor where he tells about events in which he participated during his youth (Il. 7, 124-60; Il. 11, 656-803; and Il. 23, 626-50), see Alden (1981, p. 74-111).
} 
Polypoetes, the son of Peirithous and Hippodameia, as a commander of troops that sailed to Troy from Thessaly, he adds that Polypoetes was born the day his father punished the centaurs and drove them off from the Mount Pelion.

The episode both Nestor and the main narrator evoke is the fight between the Lapiths and the centaurs, also mentioned in the Odyssey by Antinous (Il. 21, 295-304). ${ }^{19}$ As Nestor's speech, Antinous' is paradigmatic, serving to set an example of behavior to follow or to avoid.

The word used twice in the Iliad to refer to the centaurs ( $\varphi$ í, Il. 1, 268 and Il. 2, 743) has been abandoned in that passage of the Odyssey in favor of Kévtavoos (Il. 21, 295 and 303). This word appears in the Iliad once, associated with Chiron (Il. 11, 832), when Eurypylus, hurt by an arrow that is still in his thigh, asks Patroclus to apply the drugs ( $\varphi \alpha \dot{\rho} \mu \alpha \kappa \alpha$ ) in whose use he was said to have been instructed by Achilles who, in his turn, was taught by Chiron, the

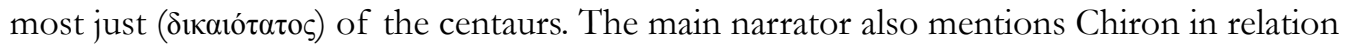
to healing drugs ( $\varphi \alpha ́ \rho \mu \alpha \kappa \alpha)$ in Il. 4, 219, when Machaon applied on Menelaus' arrow-wound the drugs that once Chiron gave to his father.

Chiron is mentioned two more times in the Iliad $(16,143=19,390)$ by the same

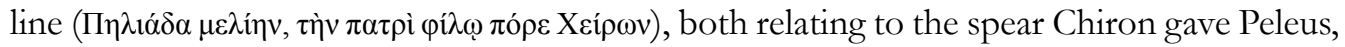
which was then given to Achilles. The narrator mentions it in book 16 in Patroclus' arming scene, in which he wears Achilles' armor, except for the famous spear, because only Achilles could wield it. In Achilles' arming scene in book 19, the son of Peleus finally takes the spear out of its case.

We can see, then, that in the Iliad Chiron is always mentioned as a benefactor, directly teaching the use of healing drugs to Machaon's father and to Achilles. He is mainly Achilles' benefactor by also providing the special spear passed down to him. The other centaurs are mentioned only in relation to the episode of the battle between them and the Lapiths,

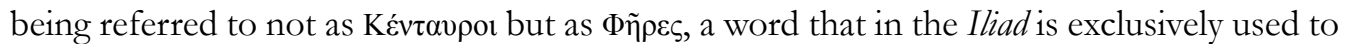
denote them. ${ }^{20}$ The poet does not describe their physiology as hybrids of man and horse,

\footnotetext{
${ }^{19}$ In a speech directed to Odysseus disguised as a beggar, Antinous reprehends the beggar for asking to take part in the bow-and-arrow contest. The suitor, implying that the beggar is drunk, mentions how the wine made the centaur Eurytion behave inappropriately at Peirithous' hall, which caused the heroes to take Eurytion outside and cut his ears and nose, which, by its turn, was the beginning of the quarrel between men and centaurs. Eurytion's fate functions as a warning to the beggar: from the point of view of Antinous, both centaur's and beggar's behavior exceed what is appropriate to the measure of hospitality, the xenia. From the point of view of the external audience, however, that can appear ironic, since Antinous and the other suitors are the ones transgressing the xenia themselves. The punishment will be exerted on the abusive guests, like it was on Eurytion, but it is the suitors who will suffer by the hands of the beggar, who is Odysseus himself. As Alden (2017, p. 3-4) has pointed out, ' $[\ldots]$ the poet is using Eurytion as an analogy for Antinous and the suitors, who have drunk as heavily as the Centaur. [...] Antinous cannot see that he is telling the story against himself'. ${ }^{20}$ Being the Aeolic equivalent of the Ionic $\theta \eta \dot{n} \rho$, which is more commonly used to refer to wild animals in general, it has been considered by Kirk (1985, p. 80-1) as an indication of the Aeolic origin of
} 
leaving us only with 'mountain-dwelling' and 'hairy beasts'. ${ }^{21}$ What he focuses on, instead, is their behavior.

While the centaurs have a paradigmatic function in Nestor's speech (and in Antinous' in the Odyssey) as an example of behavior to avoid, Chiron functions as a paragon of knowledge about healing techniques, a crucial kind of knowledge in war. His close connection to Achilles is not only through that wisdom, but also through the spear, a weapon that sets Achilles apart from the other fighters of his generation for he is the only one able to use it.

Regarding the paradigmatic function of Nestor's speech, Alden (2001, p. 80-2) adds 'two levels' of significance to it. The first one concerns the action of bride stealing that the centaurs' episode evokes. The Trojans, like the centaurs, are bride-stealers and, as Nestor's advice helped defeat the centaurs in the past, it can be helpful against the Trojans in the present. The second is associated, though somewhat inferentially and indirectly, with the immediate quarrel: taking Briseis from Achilles, Agamemnon is appropriating a woman who belongs to someone else and hence behaving like the centaurs and the Trojans. ${ }^{22}$

When declaring his participation in the battle against the centaurs, an event that happened in the previous generation, Nestor functions as a link between that generation and the present one. It might be that Nestor's speech has yet another level, as he had a role in the punishment for the excess committed by a race of creatures whose most just member is closely linked to Achilles. It is not that Nestor is implying any kind of harassment against Achilles with his speech, but it does serve to remind Achilles, who had a personal relation with a centaur, that Nestor was once successful defeating those wild creatures.

earlier hexameter poems that possibly existed about the centaurs, who were said to inhabit the Mount Pelion, located in the Aeolic-speaking region of Magnesia. Against the view of an earlier Aeolic phase preceding an Ionic one, but favoring the exchange between contemporary Ionian and Aeolic epic traditions, see Jones (2012).

${ }^{21}$ I do not consider the absence of description of these and other creatures in the Iliad as the result of the poet avoiding the 'fantastic' (see below that the Chimera will receive a description). The primary audience of the poem was likely familiar with the narratives in which those creatures featured. I believe, as Lord (1971) has shown, that the poet chooses certain elements for one particular performance of that tale and can leave those elements aside when he judges it is best, according to the oimè ('path') he chose for his song at that performative occasion. The poet can tell the same tale in a long or in a short way, expanding certain elements or making them brief. Homer did not dismiss the descriptions of those creatures in the Iliad on the account of avoiding the fantastic: he could have used the stock of descriptions if he wanted to extend his performance and provide elements that are more ornamental to that particular tale he was telling.

${ }^{22}$ Alden (2017, p. 3-4) also mentions that Achilles calls Agamemnon ỏvoßa act with drunkenness, an important feature in the story of the Lapiths and the centaurs as mentioned in the Odyssey (cf. Antinous' use of oivoßapeíwv at Il. 21, 304 to refer to the centaur Eurytion). 


\section{BRIAREUS AND TyPHOEUS: THE FARTHER PAST}

The Hundred-Hander Briareus and Typhoeus are briefly mentioned in the Iliad; Typhoeus in an even briefer fashion than Briareus. They obviously do not belong to the previous generation of heroes; according to the Theogony, they were born when the cosmos was not yet under Zeus' rule.

Briareus' mention is in Achilles' speech, when he asks his mother'Thetis to go to Zeus and beg him not to let her son be without honor (Il. 1, 365-412). ${ }^{23}$ Achilles reminds Thetis of when she released Briareus (Il. 1, 401-6) to prevent Zeus from being bound by some of

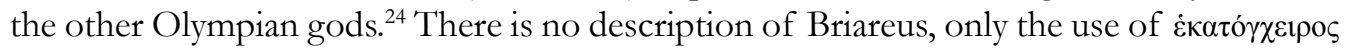
('hundred-hander'), a word that is singularly known from this passage and should include his two brothers Kottos and Gyges (cf. Th. 147-53). Achilles also mentions the different names gods and mortals assign to Briareus, this one being the name gods call him, Aegeon being his name among the mortals. ${ }^{25}$ It makes sense that, as the son of a goddess, Achilles knows Briareus by both his names.

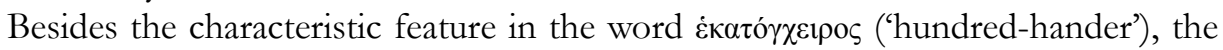
Iliad displays little more information about Briareus. First, it states that it was enough for Briareus only to sit next to Zeus to prevent the other gods from attempting to bind him; and second, that Briareus is better than his father in strength. The Iliad does not state who Briareus' father is, but in the Theogony (132-154) he is the son of Uranos (Heaven), and Briareus and his two brothers are born from the union of Gaia and Uranos in the beginning of the cosmos, along with the Cyclopes (139-146 - also a group of three), and the twelve children who will be given the collective name of Titans (132-138; 207-210). The Theogony mentions that their father hated Briareus, Kottos and Gyges on the account of their appearance and size (617-620), which does not contradict the statement in the Iliad that Briareus' strength surpassed his father's. ${ }^{26}$

\footnotetext{
${ }^{23}$ Slatkin (2011 [1991], p. 52-71) devotes special attention to the episode of Achilles' prayer to his mother in which he mentions Briareus.

${ }^{24}$ Among the gods, who are immortals, the act of being bound is the ultimate punishment. See Slatkin (2011 [1991], p. 61ff).

${ }^{25}$ There are other instances of this kind of distinction between a divine and a mortal name in the

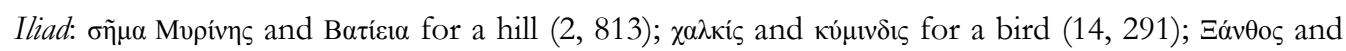

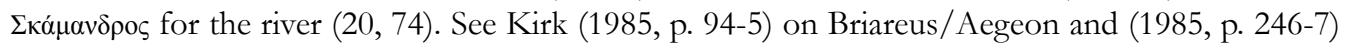

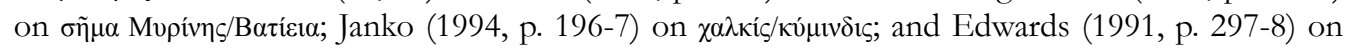
$\Xi \alpha ́ v \theta o \zeta / \Sigma \kappa \alpha ́ \mu \alpha v \delta \rho o s . ~ S e e ~ a l s o ~ H o o k e r ~(1980)$ and Fowler (1988), specifically about Briareus/Aegeon. All the instances of double naming are mentioned by the main narrator, except Briareus/Aegeon by Achilles, indicating that he has access to privileged information about the gods, a kind of access the Muses also grant the poets.

${ }^{26}$ For the debate on the line that says Briareus is stronger than his father (Iliad 1, 404), see Slatkin (2011 [1991], p. 62, n. 17). I agree with Slatkin that the line does not refer to an etymological gloss of Briareus' name, but gives the reason why Thetis summoned him. For the discussion regarding Briareus' father, see Willcock (1964, p. 143-4), and Hooker (1980). I do not see a reason why Briareus cannot be a son of Uranos in the Iliad, as he is in the Theogony.
} 
The Theogony provides the Hundred-Handers with a description in which they are said to have a hundred arms (or hands) and fifty heads each, and depicts them as extremely strong (147-53). ${ }^{27}$ Following Gaia's advice, Zeus and his siblings released them (624-6), as they apparently remained imprisoned even after Cronus castrated his father Uranos and freed his other brothers and sisters. Gaia advises Zeus to release them in order to help fight his uncles and aunts, the Titans, against whom they had been struggling for a long time. The Hundred-Handers, then, worked as heavy artillery, throwing rocks against their own brothers and sisters with their hundred arms each. ${ }^{28}$ The role of Zeus' helpers assures them a role in his order as guardians of the gates of Tartarus, where the Titans were imprisoned (729-35; 810-7). Briareus, particularly, also seems to have a further special role in the Theogony, as Poseidon gives him one of his daughters in marriage (817-9). That relationship may explain why Thetis, a sea-goddess, calls forth Briareus and not any other of the two Hundred-Handers in Zeus' defense. ${ }^{29}$

In the Iliad, the mention to this remote figure has a purpose in Achilles' speech: to remind his mother of how important she was for Zeus maintaining his position as a ruler over the other gods, a position that Briareus helped to secure at least twice. For that, she is in a position to ask Zeus a favor, reminding him of her action (Il. 1, 407). ${ }^{30}$ The episode indicates Achilles' awareness of some of the things that happened among the Olympians, with his goddess mother telling him stories about them, a kind of knowledge that the Muses are also able to give the poets (cf. Theogony 24-8). Achilles acquires knowledge from no less than a centaur and his goddess mother.

As for Typhoeus, he is mentioned by the narrator $(I l .2,781-5)$ in a simile for the trembling Earth (or Gaia) under the marching of the Achaean army. She trembled as when Zeus got angry and thunderbolted the earth around the place in which Typhoeus rests. Along with the Titans in the Theogony, Typhoeus (or Typhon) is a challenger of Zeus' rule, being the last enemy he will fight in order finally to establish himself as the supreme ruler of the

\footnotetext{
${ }^{27}$ For the language used in the description of the Cyclopes and the Hundred-Handers in the Theogony, see Vergados (2013) and Zanon (2018, p. $110 \mathrm{ff})$.

${ }^{28}$ The Titanomachy is narrated in the Theogony 664-712. Notice how articulate the Hundred-Handers are in their conversation with Zeus, in which they are convinced to fight at Zeus' side (642-63). It is also worth noticing the touching image of those huge creatures with their hundred arms and fifty heads sitting alone at the edges of the earth (617-23).

${ }^{29}$ It is worth mentioning the relation between the name by which the mortals call him (Airai $\left.\omega v\right)$ with the Aegean Sea.

${ }^{30}$ The importance of Thetis' act regarding Zeus and Briareus is noticed by Slatkin (2011 [1991], p. 61) as 'nothing less than supreme: an act that restores the cosmic equilibrium [...]'. She adds that Briareus' narrative function is to be a reminder of Zeus' final mastery in the succession myth struggle, as he does not need to perform any act besides sitting next to Zeus. It is interesting, however, that the episode is not explicitly mentioned by Thetis to Zeus in their conversation (Il. 1, 503-10; 514-6), although it is possibly implied. See also Muellner (1996, p. 121), for the metonymic relation that this episode represents between the Theogony and the first line of the Iliad: by narrating this episode, 'Achilles makes his own menis as much an aspect of Zeus's cosmic status as his own'.
} 
cosmos. ${ }^{31}$ Like the Hundred-Handers, Typhoeus is also described in the Theogony (820-41), albeit the Iliad poet does not give a physical description of him either. Being the son of Gaia and Tartarus, he has a hundred serpent heads with fire in his eyes and he produces multiple sounds: sometimes sounding for the gods to understand, other times sounding like a bull, or lions, or puppies, or even hissing. The description of the battle against him is of cosmic proportions: the earth, the sky, the seas, even Hades and the Titans were shaken both by Zeus' thunderbolts and by the fire and wind that came from the creature.

By comparing the marching of the Achaean army to Typhoeus thunderbolted by Zeus, the poet seems to emphasize the army's size, being big enough to make the earth tremble under its feet in the same fashion. The emphasis perfectly fits the context of the Catalogue of Ships, in which the poet enumerates the enormous size of the Achaean army. ${ }^{32}$

\section{The 'DOg OF LOATHEd HADES' AND THE 'SEA-MONSTER'}

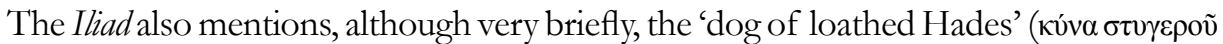

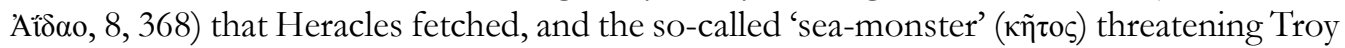
that Heracles killed (20, 144ff.). Neither is described, and Cerberus is not even mentioned by his name. However, those very brief mentions evoke a figure that is frequently present in speeches about the past in the Iliad: Heracles, the hero most associated with the activity of monster slaying in ancient Greek tradition (along with Perseus and Theseus). There are several mentions of him and some of his deeds in the Iliad, and by that constant invocation, it is not farfetched to say that Heracles is a paradigmatic figure for Achilles in the poem. ${ }^{33}$

${ }^{31}$ For the Typhonomachy, cf. Theogony 820-80. In Hesiod's Theogony, Typhoeus is referred to as Tupóov

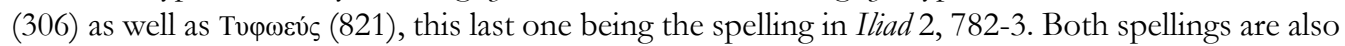

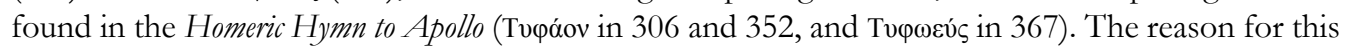
variation is unknown (cf. West (1997 [1966]), p. 252).

${ }^{32}$ Kelly (2010) pointed out that this simile might imply the role of the Achaean army in the maintenance of Zeus' order, as they are advancing to quell an offense against Zeus; the effect their marching has on earth is like when Zeus lashed Typhoeus.

${ }^{33}$ Heracles is mentioned in the Iliad in the Catalogue of Ships as Tlepolemo's father (2, 657-70); in Dione's speech to her daughter Aphrodite (5, 391-404); in Tlepolemo's speech to Sarpedon (5, 628-42); in Sarpedon's reply to Tlepolemos, mentioning Heracles' destruction of Troy (5, 646ff.); in Athena's speech to Hera mentioning the episode in which Eurystheus sent Heracles to fetch the 'loathed dog of Hades' $(8,364-69)$; in Nestor's speech to Patroclus mentioning when Heracles went to Pylos and killed all his eleven brothers $(11,693 \mathrm{ff}$.); in Sleep's speech to Hera mentioning when Heracles left Troy after destroying it, reminding her that the last time she asked him to put Zeus to sleep, she redirected Heracles to Cos, far away from his family (14, 247ff.); in Hera's reply to Sleep saying that Zeus does not care about the Trojans as much as he cared about his son Heracles (14, 263ff.); in the same episode mentioned by Zeus to Hera (15, 24-30), when he adds that he then protected Heracles and conducted him back to Argos; in the narrator mentions of Periphetes' father, Copreus, who was Eurystheus' messenger to Heracles $(I l .15,640)$; in Achilles speech to his mother Thetis mentioning how Heracles was subjugated by the moira and Hera, and he himself will also have similar moira and 
Achilles himself, in a speech to his mother Thetis, draws a comparison between himself and Heracles, saying that both of them will have the same moira (Il. 18, 117ff.): like Heracles, he will die, but first he will acquire kleos and make the Trojan women cry.

Working again as a link between generations, Nestor tells Patroclus of when Heracles went to Pylos and killed his eleven brothers (Il. 11, 693ff.), being the only survivor among them of Heracles' destructive power. ${ }^{34}$

Heracles is Tlepolemos' father (Il. 2, 657-70; 5, 628-42) and in his exchange with Sarpedon (Il. 5, 628ff.) they mention the episode of Heracles' destruction of Troy, an important one for the whole Trojan tradition. ${ }^{35}$ Heracles is not only a 'monster-slayer' hero but he is also a siege-hero, as the Homeric ones, and the reason for that first destruction of Troy, as Sarpedon underlines, was Laomedon's refusal to give Heracles the horses after which he had come to Troy. Then, we have to fill in the gap left for us in the poem, although possibly not for the intended audience. Those horses were supposed to be Heracles' reward

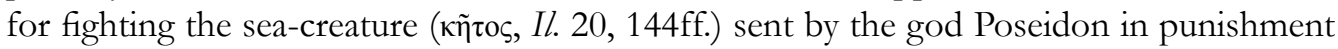
for Laomedon's non-payment for the building of Troy's walls. Heracles freed Troy from the menace of the sea-creature and destroyed the city soon afterwards for not receiving Laomedon's immortal horses as payment for that deed. Although we do not have the whole account in the Iliad, it is a case in which the hero does not receive the reward (or apportion, geras) acknowledging his timé, something that bears a strong resemblance to what happened to Achilles in the beginning of the poem. Heracles seems to be strategically placed by the poet in the narrative background as a powerful shadow from the past against which Achilles measures himself.

\section{Chimera}

The only episode in the Iliad in which a fantastic creature is described is the embedded narrative about Bellerophon (Il. 6, 145-236), told by Glaucus when he encounters Diomedes in battle. Bellerophon is Glaucus' grandfather and was sent by the Argive king Proetus to the king of Lycia, who was his father-in-law, under the (false) accusation of having engaged in sexual misconduct towards Proetus' wife. Instead of killing him, as the signs he bore told the Lycian king to do, he sends Bellerophon on several quests hoping that he will be eventually killed. However, it is Bellerophon who, besides the Chimera (Il. 6, 178-82), kills many people: the best men of Lycia who ambushed him (Il. 6, 187-90); the Amazons (Il. 6, 186); the Solymi (Il. 6, 184-5). In the face of Bellerophon's deeds, the king of Lycia recognized him as the offspring of a god and gave him his daughter and his kingdom. It is in this passage that we find the only description of what we call a 'monster' in the Iliad (Il. 6, 178-83).

die (Il. 18, 117ff.); in Agamemnon's speech narrating the episode in which Heracles is born (Il. 19, 95ff.) and mentioning how Zeus suffered seeing his son executing the labors imposed by Eurystheus (Il. 19, 132-3). See Kelly (2007, p. 310-12).

${ }^{34}$ There is a frequent association of Heracles and bie in the Iliad (see O'Maley, 2018, p. 116-19).

${ }^{35}$ This episode is also brought up by Sleep in his reply to Hera (Il. 14, $\left.247 \mathrm{ff}.\right)$. 
The first thing the poem states about the Chimera is that she is of divine stock, not human (Il. 6,180). ${ }^{36}$ Her body is composed of three different creatures, a lion in the fore part, a serpent in the rear and a she-goat in the middle. ${ }^{37}$ She is a fire-breathing creature both in the Iliad and in the Theogony (319 and 324). Since Bellerophon killed her, she was mortal, despite being divine. In the Theogony she belongs to the lineage of Phorkys and Keto, who, by their turn, are children of Pontos (Sea) and Gaia. ${ }^{38}$ In Iliad 16, 329 the narrator mentions that she was raised by a certain Amisodarus, who was the father of Sarpedon's comrades

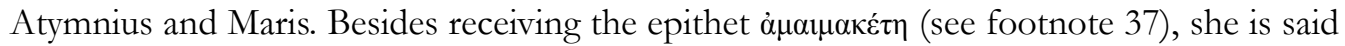

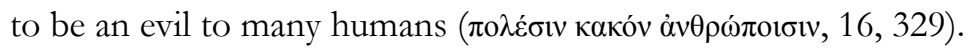

Killing the Chimera was one of the deeds tasked to Bellerophon by the King of

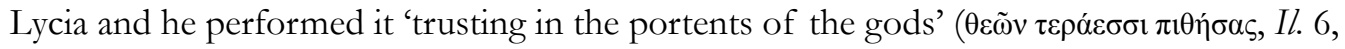
183). The Iliad does not tell what those portents were, and it is possible that Bellerophon's deeds were narrated in longer accounts. Kirk (1990, p. 184) wonders if those 'portents of the gods' could be a veiled reference to Pegasus just to refute it immediately. ${ }^{39}$ Pegasus is linked by Hesiod in the Theogony (325) with Bellerophon as the slayers of the Chimera.

It is curious that in this embedded story the topic of 'signs' is so frequently evoked. Proetus sends Bellerophon to Lycia carrying with him $\sigma \eta \dot{\mu} \alpha \tau \alpha \lambda \nu \gamma \rho \alpha$, and once sent to kill the Chimera, he did it 'trusting in the signs of the gods' ( $\theta \varepsilon \tilde{\omega} v \tau \varepsilon \rho \alpha \dot{\varepsilon \sigma \sigma l} \pi \mathrm{\imath} \theta \dot{\eta} \sigma \alpha \varsigma) .{ }^{40} \mathrm{It}$ is possible that the episode of Bellerophon was traditionally associated with the element of signs, the

${ }^{36}$ In lines Il. 6, 179 and 16, 329 Chimera receives the epithet $\dot{\alpha} \mu \alpha \mu \alpha \kappa \dot{\varepsilon} \tau \eta$, whose meaning is obscure

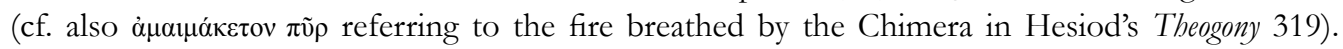
Cunliffe relates it to $\mu \alpha \kappa-$, $\mu \alpha \kappa \rho$ ó, then expressing her size. LSJ suggests 'irresistible' in connection with

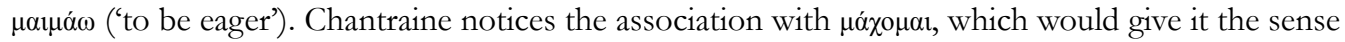
of 'invincible', but there is no etymological ground for that. Beekes refutes all those connections, assuming that the epithet is of unknown meaning. LfgrE also glosses it as of unknown meaning.

${ }^{37}$ Compare to this the description of the Chimera in the Theogony 319-25, where she has three heads: one of a lion, the other of a she-goat and the last one of a serpent. Lines 323-4 are the same as Il. 6, 181-2, and were considered interpolations from the Iliad by Wolf (followed by West). In the Iliad there is no line that relates the three animals to the number of heads, so it is assumed that they concern her body.

${ }^{38}$ The union of Pontos and Gaia in the Theogony (237ff.) is the only instance in which the male part of the couple, not the female, gives birth to their children.

${ }^{39}$ Besides Kirk's arguments, if it referred to Pegasus, there would have to be an explanation why $\tau \dot{\varepsilon}$ pas is in the plural form.

${ }^{40}$ Notice the repetition of the word on $\mu \alpha$ in this embedded story: Il. 6, 68, 176, and 178. The half-line $\theta \varepsilon \tilde{v} v \tau \varepsilon \rho \dot{\alpha} \varepsilon \sigma \sigma \mathrm{\imath} \pi \theta \eta \dot{\sigma} \sigma \varsigma \varsigma_{\varsigma}$ is also used in relation to Tydeus in Il. 4, 398 in Agamemnon's speech to Diomedes

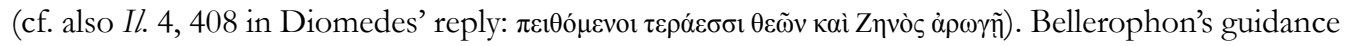
by the gods is also something mentioned by an expression usually not well understood, as $I l .6,171$ $\theta \varepsilon \tilde{\omega} v \dot{v} \pi \dot{\alpha} \mu v \dot{\mu o v ı ~} \pi$ o $\mu \pi \tilde{n}$ ('by the flawless guidance of the gods'). At some point in Bellerophon's story he ceases being favored by the gods and starts being hated by them, as Il. 6, 200 tells: 'But when he

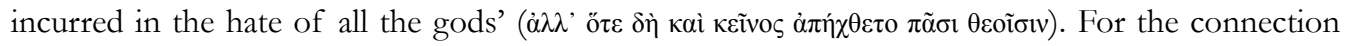
between Bellerophon's and Tydeus' stories, see Assunção (1997, p. 48-9). Cf. also n. 58 in Assunção 
ones he carries and the ones the gods send to him, and what we have in the Iliad might be the poet abbreviating it in order to avoid extending an already long embedded narrative, although keeping the associative elements of the traditional multiform. ${ }^{41}$

As stated above, the Chimera is the only fantastic creature described in the Iliad and I tend to agree with Mackie (2008), that this uniqueness is not fortuitous. In his chapter entitled 'Monsters' (p. 21-59; especially p. 30-50), Mackie shows several parallels between the characterizations of the Chimera and Achilles. They both have a divine nature (cf. Il. 6, 180, $\theta \varepsilon i ̃ o v$ ývos, for the Chimera) as well as a triple nature: Achilles, besides being part human and part divine by birth, is part beast in his excessive violence. He is $\delta \varepsilon t v o ́ \varsigma$ ('wondrous', 'terrible', 'dire', 'fearsome') like the Chimera (cf. Il. 6, 182 for the Chimera; Il. 11, 653-4 for Achilles), an adjective applied to him by no one else than Patroclus. Hecuba calls him $\dot{\omega} \mu \eta \sigma \tau$ ' $($ 'one who eats raw flesh'), a word that is usually associated in the Iliad to birds of prey, fish and dogs and is related to the savage character of the creature (Il.11, 454; 22, 67; $24,82)$ and in Hesiod's Theogony is used for Cerberus and Echdina, both closely related to Chimera genealogically. In Hesiod's poem, the Chimera is $\pi$ o $\delta \omega \kappa \eta \tilde{~} \alpha$ ('of swift foot', 320),

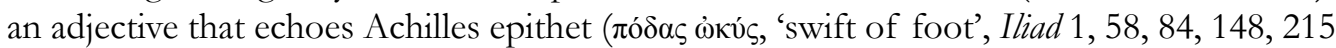
etc.). ${ }^{42}$ Achilles is terrifying as well, as Agamemnon (Il. 1, 146) and the goddess Iris (Il. 18,

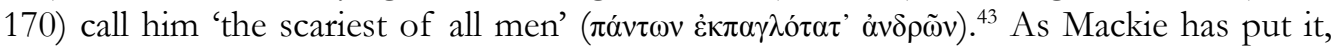
Achilles is a sort of Hector's Chimera, that terrorizes Troy and 'brings an otherworldly kind of terror to his opponents in the battlefield' (Mackie, 2008, p. 50). ${ }^{44}$

\section{Conclusion}

Although I am extrapolating from the usual range of features associated with the socalled monsters in Homer - creatures that are better called fantastic or prodigious -, several of those creatures mentioned in the Iliad can be linked to Achilles someway or another. Furthermore, there are several aspects of the fantastic related to Achilles as a character, and to say that the poet of the Iliad avoids the fantastic may hinder a possible frame of reference for understanding this chimerical character.

Achilles has a peculiar nature in the Iliad and that nature is already indicated in the first word of the poem: his wrath is not human, it is menis, an emotion restricted to gods

for the possible interpretations of кaí ('also') in line Il. 6, 200. It is noteworthy that Bellerophon was the grandson of Sisyphus (cf. Il. 6, 153-4).

${ }^{41}$ For how the poets choose within the traditional material and for the concept of multiform, see Lord (1971).

${ }^{42}$ Although it is also the epithet of the goddess Iris as in Il. 2, 790, 795 etc.

${ }^{43}$ See, however, Il. 20, 389, where Achilles himself uses the expression in regard to Iphition, who was the son of a nymph, after killing him.

${ }^{44}$ Mackie draws several other parallels between Achilles and the Chimera that I omitted here. For the whole of his argument, see the chapter I referred to in the text (Mackie, 2008, p. 21-59). 
and Achilles. ${ }^{45} \mathrm{He}$ is not only son of a goddess and favored by Zeus, a centaur also took part in his life; both his sets of armor were made by a god; and even if he is not as powerful as Heracles was, he is as menacing to Troy as the $\kappa \tilde{\eta} \tau o \varsigma$ once was. ${ }^{46}$ Achilles is prodigious ( $\pi \varepsilon \lambda \omega ́ p ı \varsigma, ~ I l .21,527$ and 22, 92).$^{47}$ His horses were born from Zephyrus and a Harpy (Il. 16, 148-51): Xanthus and Balius are capable of crying the death of Patroclus (Il. 17, 426-29), while Xanthus receives from Hera the temporary ability to speak (Il. 19, 404-17). ${ }^{48}$ It is only fair to conclude that the Iliad depicts Achilles as the most formidable warrior of his generation.

Additionally, Achilles fights the river-god Scamander in a long episode in Il. 21, 1-384, an instance that Griffin might have failed to take into consideration when he underlined the avoidance of the fantastic element in the Iliad. In that episode - which is not even in an embedded narrative, but in the main one - the river Scamander (or Xanthus) is so full of bodies of Achilles' victims that its course is starting to be clogged, which menaces the existence of the river-god itself. Scamander, then, literally rises up against Achilles, and an interesting inversion seems to be occurring. It is not Achilles who is fighting the river as much as the river is fighting Achilles. His excessive and unstoppable violence in the face of Scamander seems to put him on the other side of the hero versus menacing creature. It is Achilles who seems to be the menacing, prodigious creature to be fought either by a rivergod or by Hector and the Trojans. ${ }^{49}$

\section{REFERENCES}

\section{Text EDITIONS}

MOST, Glenn W. (Ed. and transl.). Hesiod: The Shield, Catalogue of women, Other fragments. Cambridge, MA: Harvard University Press, 2007. v. 2. (Loeb Classical Library, 503).

MOST, Glenn W. Hesiod: Theogony, Works and days, Testimonia. Cambridge, MA: Harvard University Press, 2006. v. 1. (Loeb Classical Library, 57N).

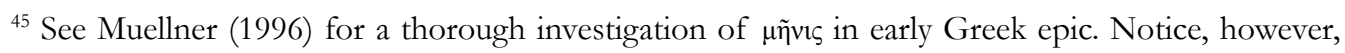
that the verb غ̇ $\pi u \mu \eta v i \omega$ ('cherish resentment against') is associated with Aeneas in Il. 13, 460. Aeneas, nevertheless, is also a son of a goddess, like Achilles.

${ }^{46} \mathrm{I}$ find it significant of the feral aspect of Achilles the way he addresses Hector in Il.22, $621 \mathrm{ff}$. saying that as there are no oaths between lions and men, it is also not possible for them to share oaths or be friends. Although there is no indication that the lion part of the simile refers to Achilles himself, the

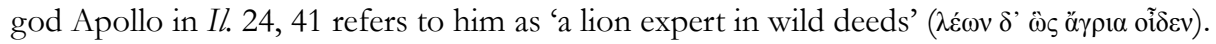

${ }^{47}$ See Parry (1971, p. 157-8) for the non-ornamental character of the epithet. For a list of referents to that adjective, see Zanon (2018, p. 314-5).

${ }^{48} \mathrm{It}$ is interesting that the Erinyes are the ones who take the horse voice away (Il. 19, 419).

${ }^{49}$ The notion of Achilles as assuming the role of a menacing creature that terrorizes Troy and the way in which the Iliad adapts traditional accounts of monster-slaying heroes to its own milieu are well explored by Mackie (2008), from which this paper has drawn extensively.
} 
RICHARDSON, Nicholas J. Three Homeric hymns: to Apollo, Hermes, and Aphrodite, bymns 3, 4, and 5. Cambridge: Cambridge University Press, 2010. (Cambridge Greek and Latin classics). WEST, Martin L. Hesiod, Theogony: edited with prolegomena and commentary. Oxford: Clarendon Press, 1997 [1966].

WEST, Martin L. (Ed.) Homerus: Ilias. Stuttgart; Leipzig: De Gruyter, 1998. v. 1. (Bibliotheca scriptorum graecorum et romanorum teubneriana).

WEST, Martin L. (Ed.). Homerus: Ilias. Stuttgart; Leipzig: De Gruyter, 2000. v. 2. (Bibliotheca scriptorum graecorum et romanorum teubneriana).

WEST, Martin L. (Ed.). Homerus: Odyssea. Berlin: De Gruyter, 2017. (Bibliotheca scriptorum graecorum et romanorum teubneriana).

\section{Critical}

ACKERMANN, Hans Christoph; GISLER, Jean-Robert; KAHIL, Lilly. Lexicon iconographicum mythologiae classicae (LIMC). Zürich: Artemis, 1981.

ALDEN, Maureen J. Homer beside himself:para-narratives in the Iliad. Oxford: Oxford University Press, 2001.

ALDEN, Maureen J. Para-narratives in the Odyssey: stories in the frame. Oxford: Oxford University Press, 2017.

ASSUNÇÃO, Teodoro R. Le mythe iliadique de Bellérophon. Gaia: revue interdisciplinaire sur la Grèce archä̈que, n. 1-2, p. 41-66, 1997.

AUSTIN, Norman. The function of digressions in the Iliad. Greek, Roman and Byzantine Studies, v. 7, n. 4, p. 295-312, 1966.

BEEKES, Robert. Etymological dictionary of Greek. Leiden: Brill, 2010.

CHANTRAINE, Pierre. Dictionnaire étymologique de la langue grecque. Paris: Klincksieck, 19681977. t. 1-4.

CUNLIFFE, Richard J. A lexicon of the Homeric dialect. Norman: University of Oklahoma Press, 1963. Available online at: http://stephanus.tlg.uci.edu/cunliffe.

EDWARDS, Mark W. The Iliad: a commentary. Cambridge: Cambridge University Press, 1991. v. 5 .

FOWLER, R. L. AIT- in early greek language and myth. Phoenix, v. 42, n. 2, p. 95-113, 1988.

GRIFFIN, Jasper. The epic cycle and the uniqueness of Homer. Journal of Hellenic Studies, v. 97, p. 39-53, 1977.

HAINSWORTH, Bryan. The Iliad: a commentary. Cambridge: Cambridge University Press, 1993. v. 3. 
HOOKER, J. T. AITAISN in Achilles plea to Thetis. Journal of Hellenic Studies, v. 100, p. 88-89, 1980.

JANKO, Richard. The Iliad: a commentary. Cambridge: Cambridge University Press, 1994. v. 4.

JONES, Brandtly. Relative chronology and an 'aeolic phase' of epic. In: ANDERSEN, Øivind; HAUG, Dag T. T. Relative chronology in early Greek epic poetry. Cambridge: Cambridge University Press, 2012, p. 44-64.

de JONG, Irene. Narrators and focalizers: the presentation of the story in the Iliad. London: Bristol Classical Press, 2004 [1987].

KELLY, Adrian. A referential commentary and lexicon to Homer, Iliad VIII. Oxford: Oxford University Press, 2007.

KELLY, Adrian. Hypertexting with Homer:Tlepolemus and Sarpedon on Heracles (Il. 5.628698). Trends in classics, Berlin, v. 2, p. 259-76, 2010.

KIRK, G. S. The Iliad: a commentary. Cambridge: Cambridge University Press, 1985. v. 1.

KIRK, G. S. The Iliad: a commentary. Cambridge: Cambridge University Press, 1990. v. 2.

LIDDELL, Henry; SCOTT, Robert; JONES, Henry S. A Greek-English lexicon. (9th ed.). Oxford: Clarendon Press, 1996. (available online at: http://stephanus.tlg.uci.edu/lsj)

LORD, Albert Bates. The singer of tales. New York: Athenaeum, 1971.

MACKIE, Chris J. Rivers of fire: mythic themes in Homer's Iliad. Washington, DC: New Academia Publishing, 2008.

METTTE, Hans Joachim; SNELL, Bruno. Lexikon des frühgriechischen Epos (LfgrE). Göttingen: Vandenhoek \& Ruprecht, 1979-.

MUELLNER, Leonard. The anger of Achilles: mênis in Greek epic. Ithaca: Cornell University Press, 1996.

NAGY, Gregory. The ancient Greek hero in 24 hours. Cambridge, MA: Belknap Press of Harvard University Press, 2013.

O'MALEY, James. Homer's footnotes: storytelling and the presentation of the past in the Iliad. Melbourne: University of Melbourne, 2014. (Ph.D. thesis)

PARRY, Milman. The making of Homeric verse: The collected papers of Milman Parry. Ed. Adam Parry. Oxford: Oxford University Press, 1971.

PIERUCCI, Antônio Flávio. O desencantamento do mundo: todos os passos do conceito em Max Weber. 3 ed. São Paulo: Editora 34, 2013.

SLATKIN, Laura M. The power of Thetis and selected essays. Washington, D.C.: Center of Hellenic Studies, 2011 [1991]. 
VERGADOS, Athanassios. The Cyclopes and the Hundred-Handers in Hesiod's Theogony 139-53. Hermes, v. 141, n. 1, p. 1-7, 2013.

VERSNEL, H. S. Coping with the gods: wayward readings in Greek theology. Leiden: Brill, 2011.

VEYNE, Paul. Les Grecs ont-ils cru à leurs mythes? Essai sur l'imagination constituante. Paris: Éditions du Seuil, 1983.

WEST, Martin. Towards a chronology of early Greek epic. In: ANDERSEN, Øivind; HAUG, Dag T. T. Relative chronology in early Greek epic poetry. Cambridge: Cambridge University Press, 2012, p. 224-41.

WILLCOCK, M. M. Mythological paradeigma in the Iliad. Classical Quarterly, v. 14, n. 2, p. 141-54, 1964.

ZANON, Camila A. Onde vivem os monstros: criaturas prodigiosas na poesia de Homero e Hesíodo. São Paulo: Humanitas, 2018. 